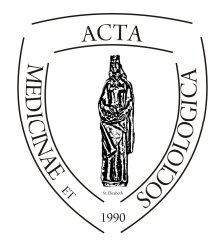

Acta Medicinae et

Sociologica (2020)

Vol. 11., Különszám. (30-42)

doi:

\title{
A fizikai aktivitási szokások vizsgálata a Myers- Briggs-féle személyiség preferenciák tükrében
}

\author{
Bartha Éva Judit ${ }^{1}$, Bácsné Bába Éva ${ }^{2}$ \\ 1 Tudományos segédmunkatárs, Debreceni Egyetem Gazdaságtudományi Kar, Sportgazdasági és - \\ menedzsment Intézet, 4032 Debrecen, Böszörményi út 138. \\ 2 Intézetigazgató egyetemi tanár, Debreceni Egyetem Gazdaságtudományi Kar, Sportgazdasági és - \\ menedzsment Intézet, 4032 Debrecen, Böszörményi út 138.
}

\begin{tabular}{|c|c|}
\hline INFO & ABSTRACT \\
\hline $\begin{array}{l}\text { Bartha Éva Judit } \\
\text { bartha.eva.judit@econ.unideb.hu }\end{array}$ & \multirow[b]{2}{*}{$\begin{array}{l}\text { Abstract. The key objective of our research is to look into } \\
\text { the fitness sector and explore how Myers-Briggs personality } \\
\text { types influence the training session attendance-related habits } \\
\text { and main motivational factors of fitness consumers. These } \\
\text { key driving factors are motivating the fitness sector consum- } \\
\text { ers to attend training session and determine the physical } \\
\text { activity of sportspeople. According to the Myers-Briggs } \\
\text { Temperament Index, extraverted - sensing - thinking - } \\
\text { judging type proved to be the most common within the sam- } \\
\text { ple. Based on our results, the period and regularity of train- } \\
\text { ing sessions does not depend on the personality of fitness } \\
\text { consumers. However, based on their main motivations, sig- } \\
\text { nificant differences have emerged in different preference } \\
\text { dichotomies. We can assume that fitness gym trainings are } \\
\text { mostly popular among sportspeople with extraverted - sens- } \\
\text { ing - thinking - judging personality type, so it is worthwhile } \\
\text { for fitness providers to consider the motivation and aims of } \\
\text { their target group. }\end{array}$} \\
\hline $\begin{array}{l}\text { Keywords: } \\
\text { fitness, fitness services, } \\
\text { Myers-Briggs, } \\
\text { personality types }\end{array}$ & \\
\hline $\begin{array}{l}\text { Kulcsszavak: } \\
\text { fitnesz, fitneszszolgálta- } \\
\text { tás, Myers-Briggs, sze- } \\
\text { mélyiségtípusok }\end{array}$ & $\begin{array}{l}\text { Absztrakt: Kutatásunk célja annak felmérése volt, hogy a } \\
\text { Myers-Briggs-féle személyiség preferenciák befolyásolják-e } \\
\text { a fitneszterembe járók edzési szokásait, valamint különböz- } \\
\text { nek-e legföbb edzésre ösztönző motivációik egymástól, } \\
\text { hiszen ezek a motiváló tényezők és célok meghatározóak } \\
\text { lehetnek abban, hogy milyen rendszeres és milyen hosszú } \\
\text { távú a testmozgásba való bekapcsolódás. A mintában leg- } \\
\text { gyakrabban előforduló személyiségtípus az MBTI alapján az } \\
\text { extrovertált - érzékelö - gondolkodó - ítéletalkotó típus } \\
\text { volt. Eredményeink azt tükrözik, hogy a sportolásba való } \\
\text { bekapcsolódás rendszeressége és időtartama nem függ sze- }\end{array}$ \\
\hline
\end{tabular}


mélyiségtől. A minta megoszlása alapján feltételezhetjük, hogy a fitnesztermi edzésekbe leginkább az extrovertált, érzékelö, gondolkodó és megítélő beállítottságú szabadidösportolók kapcsolódnak be, így a fitnesz szolgáltatóknak érdemes az erre a típusra jellemző motivációkat és célokat figyelembe véve megszólítani a kívánt célközönséget, valamint megpróbálni kialakítani egy olyan szolgáltatáscsomagot, amellyel a többi myersi típus mindennapos fizikai aktivitásban való részvételének növekedése is elősegíthetö.

A publikáció elkészítését az EFOP-3.6.1-16-2016-00022 számú projekt támogatta. A projekt az Európai Unió támogatásával, az Európai Regionális Fejlesztési Alap társfinanszírozásával valósult meg.

\section{Bevezetés}

Napjainkban elfogadott tény, hogy a fizikai aktivitás pozitív hatással van a fizikaiés mentális egészségre is. Aktív életmódról hetente legalább két-három alkalommal végzett testmozgás esetén beszélünk, amely során a szervezetet az egészség megőrzéséhez szükséges terhelés éri. Inaktivitásról ezzel szemben a szükséges testmozgás hiányakor van szó (Ács, Hécz és munkatársai 2011).

Az aktív életmód segít a kardiovaszkuláris rendszer egészségének fenntartásában, a metabolikus rendszer betegségeinek megelőzésében, a mozgatórendszer egészségének megőrzésében, valamint a mentális betegségek elkerülésében is (Oliveira, Da Costa és munkatársai 2014). Korunk legtöbb egészségügyi problémája visszavezethető a mozgásszegény életmódra. A WHO a tíz legfőbb halálok között negyedikként rangsorolja a fizikai inaktivitást, olyan egészségügyi problémák előidézőjeként, mint a túlsúly és az elhízás, az ischaemiás szívbetegség, a stroke, a 2-es típusú cukorbetegség, a magas vérnyomás, a vér magas koleszterinszintje, a csontritkulás, a csontok törékenysége, a rák egyes fajtái, a mozgatórendszer betegségei, valamint bizonyos mentális rendellenességek (WHO 2010; Pratt, Norris, Lobelo és munkatársai 2014). Janssen (2012) szerint hat krónikus betegség kapcsolható össze közvetlenül a mozgásszegény életvitellel: a stroke, a magas vérnyomás, a 2-es típusú diabétesz mellitusz, a vastagbélrák, a mellrák és a csontritkulás.

\section{A fizikai aktivitás mutatói}

Az ajánlások ellenére a világ népességére az inaktivitás a jellemző (1. ábra). Világszerte jellemző, hogy a férfiak többen folytatnak aktív életmódot, mint a nők. 


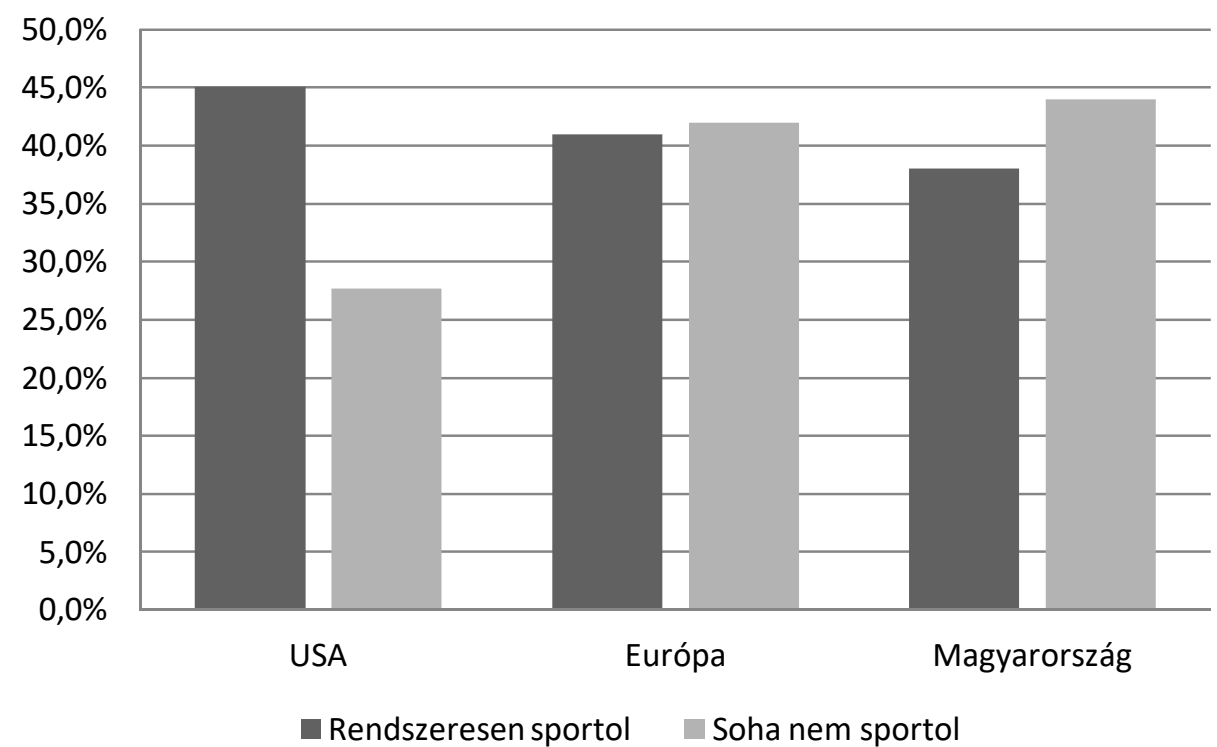

Forrás: Saját szerkesztés, Eurobarometer, 2014;Physical Activity Council, 2017 alapján

1. ábra: A rendszeres testmozgás aránya: USA, Európa, Magyarország (2013)

Az Egyesült Államokban 2016-ban a lakosság megközelítőleg egy harmada (31,7\%a) végzett az egészséges szintnek megfelelő mennyiségü testmozgást, míg 27,5\% számolt be arról, hogy teljesen inaktív életet él. Mindkét csoport aránya kis mértékben változott 2013-hoz képest, amikor az egészséges szintet elérő vagy meghaladó fizikai aktivitás a népesség 33,5\%-ára, az ajánlásokat el nem érö, de aktív életmód 11,6\%-ra, az inaktivitás 27,7\%-ra volt jellemző (Physical Activity Council, 2017).

Európa lakosságának 41\%-a végez legalább hetente egy alkalommal valamilyen sporttevékenységet vagy edzést, $42 \%$ azonban soha. Más jellegü fizikai aktivitást az európaiak 48\%-a végez, 30\%-a azonban egyáltalán nem. A fizikai aktivitásban való részvétel magasabb az északi országokban, a svédek 70, a dánok 68, a finnek 66, a hollandok 58, és a luxemburgiak 54\%-a végez legalább heti egy alkalommal mozgásos tevékenységet. Ezzel szemben a déli országokra a nagyarányú inaktivitás a jellemző: Bulgáriában a lakosság 78, Máltán 75, Portugáliában 64, Romániában és Olaszországban $60 \%$-a soha nem sportol vagy folytat más jellegü fizikai aktivitást (Eurobarometer, 2014).

Magyarország az olyan egészségmagatartás mutatók szempontjából, mint a dohányzás, alkoholfogyasztás és fizikai inaktivitás az európai rangsor végén szerepel (WHO, 2010). Az Eurobarometer 2010-es kutatása szerint hazánk népességének 77\%-a folytatott inaktív életmódot, ebböl 2013-ban a soha nem sportolók aránya $44 \%$. A valamilyen rendszerességgel sportolók aránya hazánkban 38\% (Eurobarometer, 2014). A lakosság két harmada nap tíz percnél is kevesebbet sportol. A magyarok mindössze 4,5\%-a sportol napi rendszerességgel, 3,2\% folytat izomerősítő és állóképességet fejlesztő mozgást naponta, $76 \%$ egyáltalán nem végez 
ilyen testmozgást (KSH, 2014). A rendszeresen sportolók közé a magyar lakosság nagyjából 20\%-a sorolható (Pavlik, 2015).

A fizikai aktivitás növelése jelentősen kevesebb költséggel járna, mint az inaktivitás következtében kialakuló betegségek gyógyszeres kezelése (Apor, 2012).

Az átlagpopuláció rendszeres testmozgásba való bekapcsolódását szolgálja többek között a fitnesz szektor, és a népesség számára elérhető sportlétesítményei, a fitneszklubok. Vizsgálatunk fö célkitüzése a fitnesz szektor vizsgálata valamint annak felmérése volt, hogy a Myers-Briggs-féle személyiség preferenciák befolyásolják-e a fitneszterembe járó szabadidő-sportolók edzési szokásait, órákon való részvételük gyakoriságát és rendszerességét, valamint különböznek-e legfőbb edzésre ösztönző motivációik a személyiségtípusok alapján egymástól, hiszen ezek a motiváló tényezők és célok meghatározóak lehetnek abból a szempontból, hogy milyen rendszeres és milyen hosszú távú a testmozgásba való bekapcsolódás.

\section{Anyag és módszer}

Kutatásunk során a fitneszterembe járó szabadidősportolókat kerestük meg kérdőíves megkérdezéssel, amely a következő területeket mérte fel:

- általános adatok, demográfiai jellemzők

- edzéslátogatási szokások

- edzéseken való részvételt motiváló tényezők, célok

- $\quad$ szabadidősportoló személyisége (Myers-Briggs Típus Indikátor kézikönyvének személyiség-leírásai alapján).

A fitnesztermek csoportos óráin résztvevő fitnesz fogyasztók közötti vizsgálatot online és papíralapú formában is kitölthető kérdőív segítségével végeztük. Ezekhez a szabadidősportolókhoz hólabda módszerrel juttattuk el a kérdéseket, melyekre így összesen 753 fitneszterembe járó vendég válaszolt.

Kutatásunkban törekedtünk arra, hogy olyan módszereket válasszunk, amelyek biztosítják eredményeink hitelességét és lehetővé teszik kutatásunk területének minél több oldalról történő vizsgálatát. A kérdőívekből nyert kvantitatív adatok elemzése az SPSS statisztikai program alkalmazásával történt.

A fitneszterembe járó vendégek közül összesen 753 fő töltötte ki a kérdőívet. Ebböl 500 nő (66\%) és 253 férfi (34\%). A minta összetétele korosztályok alapján a következőképpen alakult: Legnépesebb számban a 18 és 65 év közötti korúak válaszoltak a kérdésekre (összesen 647-en), ebböl 252 válaszadó 18 és 25 év közötti. Legkisebb arányban az idősebb korosztály (összesen 8 fö) és a 18 évnél fiatalabbak (98 fö) töltötték ki a kérdöívet.

A vizsgált minta szocio-demográfiai összetételét az 1. táblázatban tüntettük fel. 


\begin{tabular}{|l|l|l|}
\hline \multicolumn{2}{|c|}{ MINTA (N=753) } \\
\hline \multirow{3}{*}{ Nem } & Nö & 500 fó \\
\cline { 2 - 3 } & Férfi & 253 fö \\
\hline \multirow{5}{*}{ Életkor } & 18 év alatti & 98 fö \\
\cline { 2 - 3 } & $18-25$ év közötti & 252 fö \\
\cline { 2 - 3 } & $26-35$ év közötti & 182 fö \\
\cline { 2 - 3 } & $36-45$ év közötti & 118 fö \\
\cline { 2 - 3 } & $46-65$ év közötti & 95 fö \\
\cline { 2 - 3 } & 65 év feletti & 8 fö \\
\hline
\end{tabular}

Forrás: Saját vizsgálat, 2017 ( $N=753)$

1. táblázat: A vizsgálati minta szocio-demográfiai jellemzői

A minta szocio-demográfiai jellemzőinek áttekintése után megállapítható, hogy a fitnesztermek edzők által nyújtott szolgáltatásait a nők sokkal nagyobb számban veszik igénybe, mint a férfiak, valamint, hogy ezen edzések célközönségének leginkább a fiatal- és középkorú korosztály tekinthető. Mintánk nem tekinthető reprezentatívnak, azonban feltételezhetjük, hogy ezek az adatok tükrözik az edzéstermek látogatóinak összetételét is.

\section{Eredmények \\ Edzéslátogatási szokások}

A fitnesztermek fogyasztói körében végzett vizsgálat során kiderült, hogy a fitneszterembe járók 63\%-a, azaz a megkérdezett mintából 479 fö, már egy évnél régebben vesz részt fitnesztermi edzéseken, $26 \%$-a két hónap és egy év közötti időszak óta, és mindössze $11 \%$ jár az edzésekre egy hónapnál rövidebb ideje (2.ábra).

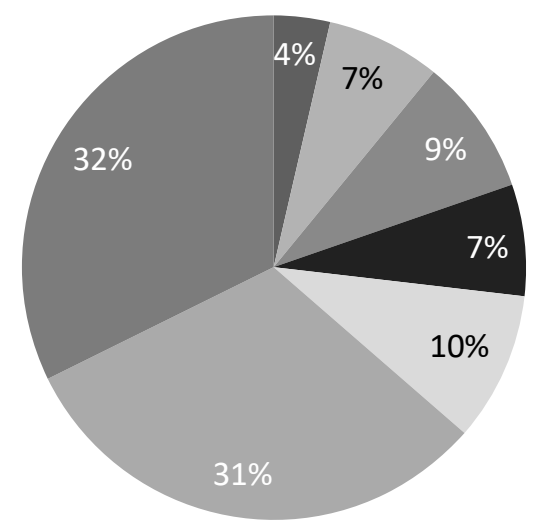

$$
\begin{aligned}
& \text { most először } \\
& \text { max. } 1 \text { hónapja } \\
& \text { 2-3 hónapja } \\
& \text { 4-6 hónapja } \\
& \text { 7-11 hónapja } \\
& \text { 1-3 éve } \\
& \text { régebben }
\end{aligned}
$$

Forrás: Saját vizsgálat, 2017 (N=753)

2. ábra: A fitnesz fogyasztók edzésre járás időszaka szerinti megoszlása 
Az, hogy a válaszadók nagy része egy évnél régebb óta jár edzeni, arra a feltételezésre ad okot, hogy a kérdőívre adott válaszaik hitelesek, valódi tapasztalatokon alapulnak.

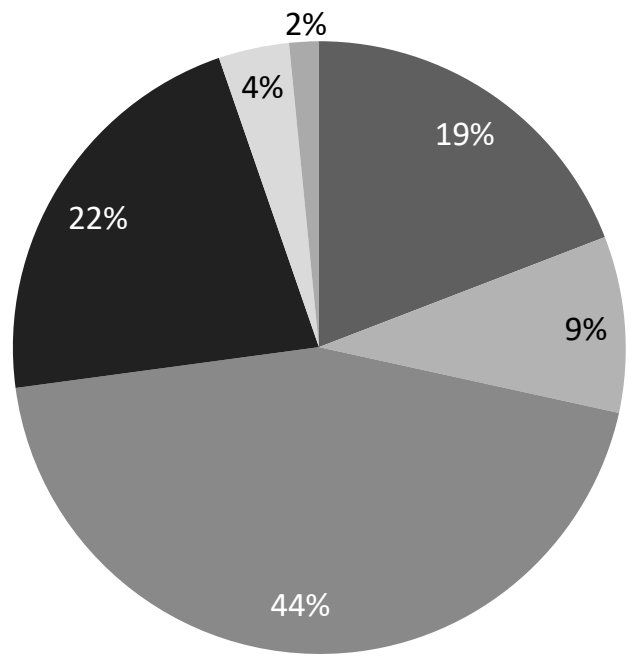

\author{
ritkábban, mint \\ havonta \\ havonta 1-2-szer
}

heti 1-2-szer

heti 3-4-szer

heti 5-6-szor

minden nap

Forrás: Saját vizsgálat, $2017(N=753)$

3. ábra: A sportolói minta edzésre járás gyakorisága szerinti megoszlása

A vizsgált minta legnagyobb részére (44\%) az jellemző, hogy heti egy-két alkalommal vesznek részt fitnesztermi edzéseken, $28 \%$ ennél is többször, így a válaszadók $72 \%$-áról elmondható, hogy legalább heti rendszerességgel jár fitneszklubokba. A megkérdezett vendégek 9\%-a havonta egy-két alkalomról számolt be, míg 19\% ennél is ritkábban edz fitneszteremben (3. ábra).

A kérdőívet kitöltő fitnesz fogyasztók nagy része minden héten részt vesz fitnesztermi edzéseken. Ez az átlag lakossághoz képest jelentős eltérés, hiszen az Eurobarometer 2014-es adatai szerint a magyarok 62\%-a soha nem sportol, míg $38 \%$-a valamilyen rendszerességgel.

Ezek az arányok nem meglepőek annak tükrében, hogy a minta összetétele, amely fitneszklubok vendégeiből áll, eleve feltételezi a rendszeres fizikai aktivitást, hiszen a lakosság inaktív része valószínüsíthetően nem látogat fitnesztermeket sem. Emiatt azt feltételezzük, hogy a minta 28\%-a, aki havonta egy-két alkalommal, vagy ritkábban jár az edzöterembe, nem minden esetben tekinthetö inaktivnak, hanem elképzelhetö, hogy a fitneszklubokon kívül más helyszinen is folytat sporttevékenységet. 


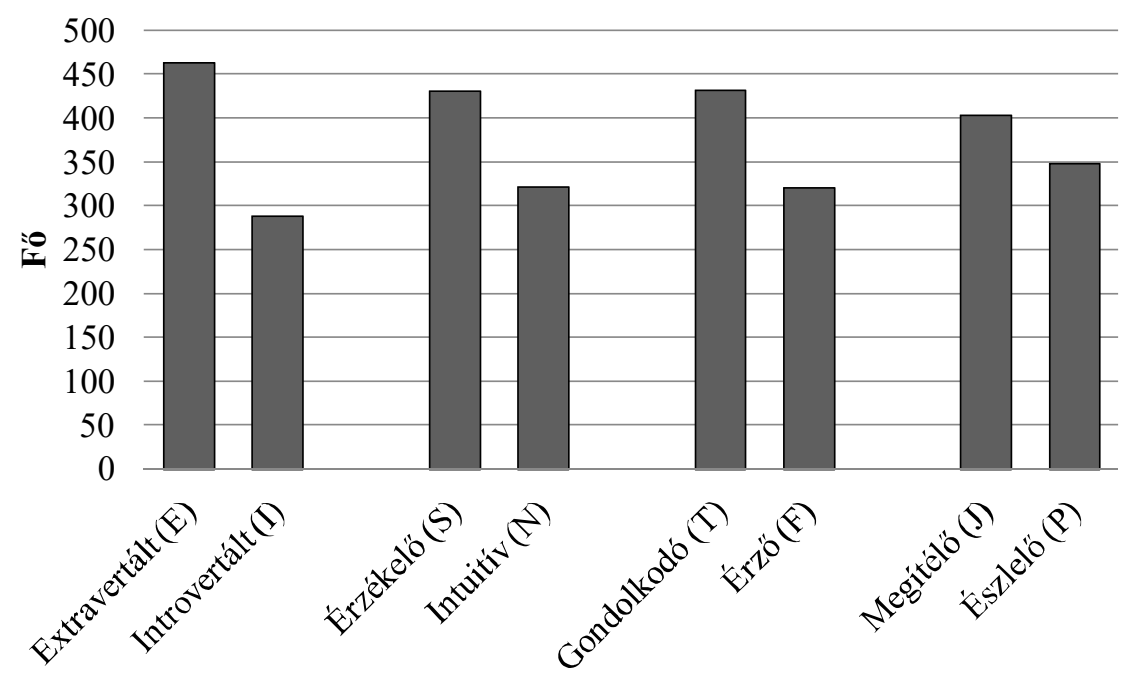

Forrás: Saját vizsgálat, 2017 (N=753)

4. ábra: A fitnesz fogyasztói minta összetétele személyiségtípusok alapján

Megvizsgáltuk a minta összetételét a Myers-Briggs-féle személyiségdimenziók szempontjából is, ennek eredményét a 4 . ábra mutatja be. A minta személyiségtípusainak elemzése során kiderült, hogy a vizsgált preferenciapárok alapján a vendégek körében az extrovertált, érzékelő, gondolkodó és megítélő beállítottság volt többségben, azonban ezek a különbségek nem voltak jelentősek.

Vizsgálatunk egyik célkitüzése annak feltérképezése volt, hogy a Myers-Briggsféle személyiségpreferenciák alapján van-e különbség a fitneszterembe járó szabadidő-sportolók fizikai aktivitásában. Eredményeink azt tükrözik, hogy a mintában a myersi személyiségtípusok szerint elkülönített csoportok között nem volt jelentős differencia ezekben a jellemzőkben, tehát sem az edzésre járás rendszerességében, sem a kitartóságban nem találtunk szignifikáns különbséget.

A fizikai aktivitás szintjét nagymértékben befolyásolja, hogy mi a szabadidősportoló legföbb motivációja. Mi ezt a fitneszklubok látogatói között igyekeztünk felmérni. A motivációk vizsgálatát azért tartottuk nélkülözhetetlennek, hiszen ezek ismerete segíthet a népesség minél szélesebb rétegeinek a mindennapos testmozgásba való bevonásában, valamint a motiváltság hosszútávú fenntartásában.

A kérdőív egyik részében megkértük a válaszadókat, hogy ötfokú Likert-skálán határozzák meg, hogy az általunk felsorolt motivációk mennyire számítanak fontosnak számukra az edzésekbe való bekapcsolódás szempontjából. Egyessel jelölték azt, amelyiket egyáltalán nem tartották fontosnak, ötös értékkel a számukra nagyon jelentős tényezőket. Ezeket az értékeket később átlagoltuk és rangsoroltuk.

Azokat a szempontokat, amelyeknek átlagértéke négynél magasabb lett, a legfontosabb ösztönző célokként határoztuk meg. Ezek közé a vizsgált mintában a következő célok kerültek: az egészség megőrzésének szándéka $(4,44)$, az állóképesség javítása $(4,36)$, az esztétikusabb külső megjelenés iránti vágy $(4,29)$, a szellemi kikapcsolódás $(4,16)$, a stresszkezelés $(4,07)$ valamint a lelki feltöltődés igénye $(4,07)$. 
A kérdőívet kitöltők számára legkevésbé fontos motiváló tényezők közé azok kerültek, amelyek mindössze három alatti értéket értek el. Ezek voltak a különböző panaszok kezelésének, megszüntetésének a lehetősége (2,95), a versengés szándéka $(1,99)$, valamint a külső elvárásoknak való megfelelés kényszere, amely akár a rokonoktól, a barátoktól, akár a munkatársak irányából érkezett, mindhárom esetben kettes alatti átlagértéket kapott.

KILPATRICK, HEBERT, BARTHOLOMEW (2010) valamint FREDERICK, RYAN (1993) korábbi eredményei azt tükrözték, hogy a fitnesztermekben sportoló vendégek leginkább a testtel kapcsolatos célok, föként az egészségmegőrzés valamint a jobb kinézet vágya miatt sportolnak. A vizsgálatunkban kapott motivációs tényezők közötti rangsor részben megfelel ezeknek a következtetéseknek, azonban fontos eredménynek tekinthető a sportolás mentális egészségre kifejtett pozitív hatásainak felismerése, hiszen mintánkban kiemelt jelentőséget tulajdonítottak a szabadidősportolók ezeknek a céloknak, mind a szellemi kikapcsolódás, mind a feltöltődés valamint a stressz kezelésének lehetősége is négyes feletti átlagértékeket kapott.

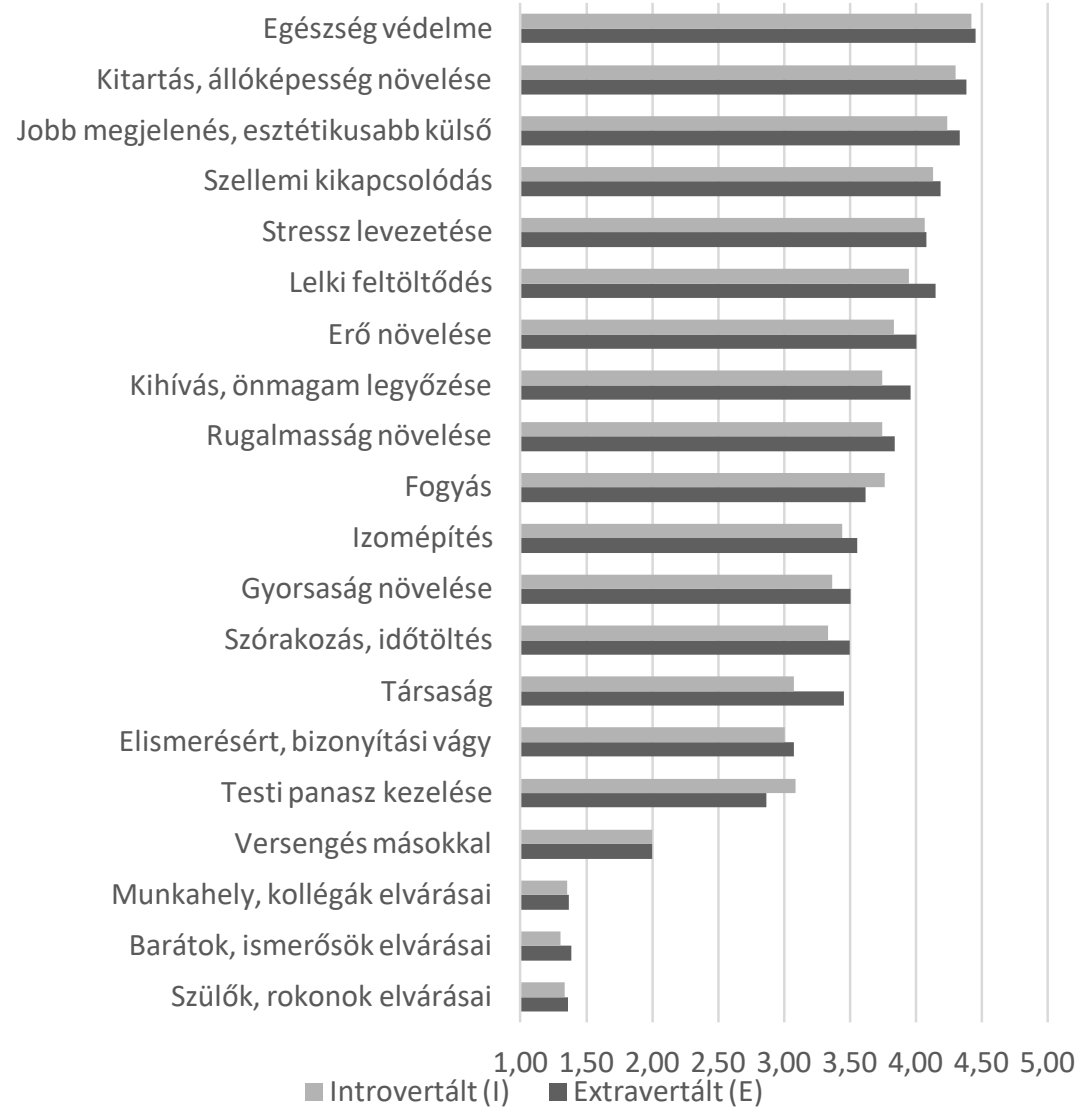

Forrás: Saját vizsgálat, 2017 (N=753)

5. ábra: A fitnesz fogyasztók legfőbb motivációi az edzéseken való részvételre (extraverzió - introverzió különbségek) 
Vizsgálatunk kiterjedt arra is, hogy befolyásolja-e a személyiség a motivációkat, van-e eltérés a felsorolt tényezők fontosságában Myers-Briggs-féle különböző személyiség-dimenziók alapján. Elsőként az extraverzió - introverzió preferenciával rendelkező sportolók motivációs azonosságait és különbségeit elemeztük (5. ábra).

Az értékelések során kapott átlagok szerint megfigyelhető tendenciák alapján feltünik, hogy szinte mindegyik motiváló tényezőnek nagyobb jelentőséget tulajdonítottak az extrovertáltak, mint az introvertáltak. Kizárólag az alak javítása fogyással, valamint a testi panasz kezelésének indoka volt, ami nagyobb értékeket kapott az introvertáltak körében. Valószínü, hogy ebben a csoportban a konkrét célok elérése nagyobb motivációs erővel bír.

A teljes mintához képest volt egy kevés eltérés, amint az ábrán is látható. $\mathrm{Az}$ extrovertáltak részéről a lelki feltöltődés $(4,15)$ megelőzte a stesszlevezetést $(4,08)$ mint motivátort, így ez lett fontossági sorrendjükben a negyedik motiváló faktor. Az introvertáltak viszont a fogyás szándékát értékelték magasabbra $(3,76)$, amely így náluk a kihívás keresésénél $(3,74)$ és a rugalmasság fejlesztésénél $(3,74)$ is fontosabb lett. Szintén eltérés volt az ő csoportjukban, hogy a testi panasz kezelésének szándéka $(3,08)$ is nagyobb jelentőséget kapott, így jobban értékelték a társaság $(3,07)$ valamint az elismerés $(3,0)$ szerepénél. Végül a kötelességek közül, mind az extrovertáltak, mind az introvertáltak eltérően rangsorolták a különböző elvárásokat. Az extrovertáltaknak a három irányból érkező elvárások közül a barátok, ismerösök elvárásai $(1,38)$ jelentenek valamennyivel többet, ezt követik a munkahelyi (1,36), majd a családi elvárások (1,35). Introvertáltaknál ez a sorrend a munkahelyi elvárásokkal $(1,35)$ kezdődik, ezt követi a család $(1,33)$, majd végük a barátok és ismerősök $(1,30)$.

\begin{tabular}{|c|c|c|c|c|}
\hline & $\begin{array}{c}\text { Személyiség- } \\
\text { preferencia }\end{array}$ & Rangátlag & Mann - Whitney U & Szignifikanciaszint \\
\hline \multirow{2}{*}{ Testi panasz kezelése } & extravertált & 364,16 & \multirow{2}{*}{61189,000} & \multirow{2}{*}{0,044} \\
\hline & introvertált & 396,27 & & \\
\hline \multirow{2}{*}{ Erő növelése } & extravertált & 390,40 & \multirow{2}{*}{60469,500} & \multirow{2}{*}{0,019} \\
\hline & introvertált & 354,24 & & \\
\hline \multirow{2}{*}{ Társaság } & extravertált & 399,21 & \multirow{2}{*}{56390,000} & \multirow{2}{*}{$\mathrm{p}<0,001$} \\
\hline & introvertált & 340,12 & & \\
\hline \multirow{2}{*}{ Kihívás } & extravertált & 391,02 & \multirow{2}{*}{60180,000} & \multirow{2}{*}{0,015} \\
\hline & introvertált & 353,24 & & \\
\hline \multirow{2}{*}{ Lelki feltöltődés } & extravertált & 391,49 & \multirow{2}{*}{59964,500} & \multirow{2}{*}{0,010} \\
\hline & introvertált & 352,49 & & \\
\hline
\end{tabular}

Forrás: Saját vizsgálat, 2017 (N=753)

2. táblázat: Szignifikáns különbségek személyiség alapján a különböző motiváló tényezők fontosságának értékelésében (extraverzió - introverzió)

Szignifikáns eltérés mutatkozott a két csoport között azzal kapcsolatban, hogy mennyire motiválja őket sportolásra a testi panaszok kezelése, az erő növelésének szándéka, a társaság, a kihívások, valamint a lelki feltöltődés (2. táblázat).

Habár a legtöbb motiváció terén nem különbözik egymástól a két csoport, eltérés volt az erő növelésének és a kihívásnak az igényében, amelyek az extrovertáltak 
számára jelentettek nagyobb motivációt. Ezek az eredmények megfelelnek az erre a beállítottságra jellemző lendületes, aktív energia attitűdnek. Ehhez hasonlóan az sem meglepő eredmény, hogy a társaság is nagyobb hatással van rájuk, mint az introvertált válaszadókra, hiszen sokkal inkább keresik és értékelik a szociális ingereket náluk. Azt azonban ki kell emelni, hogy az eredmények alapján a lelki feltöltődés szándéka is inkább az extrovertáltakat vezérli a fitnesztermi edzésekre. Ezzel szemben az introvertáltak kizárólag a testi panaszok kezelésére adtak szignifikánsan magasabb értékeket, mint az extrovertált megkérdezettek. Ennek részben lehet az az oka, hogy az introvertáltak hajlamosabbak kerülni az olyan nyüzsgő, társas közegeket, mint amilyen egy edzőterem, hacsak nincsen konkrét ok (például testi panasz) az igénybevételére.

Összességében megállapítható, hogy a válaszoknál található különbségek megfelelnek feltevéseinknek az extrovertált - introvertált preferenciával rendelkező sportolók motivációjával kapcsolatban. Nem meglepő, hogy az extrovertáltak számára a társaság, a kihívások szignifikánsan magasabb motiváló erőt jelentettek, mint az introvertált sportolóknak. Ugyanakkor érdekes a lelki feltöltődés keresésének kiemelt szerepe az extrovertáltaknál, de mivel csoportos, fitnesztermi edzésekről van szó, nyilvánvaló, hogy az extrovertáltak számára jelentős, az introvertáltakra kevésbé jellemző a lelki feltöltődésnek ez a közösségben elérhető formája.

A következő preferencia-dichotómia, amely alapján a motivációk eltéréseit elemeztük, az érzékelés és az intuíció volt. Ebben az esetben kizárólag két motiváló fakor között volt szignifikáns eltérés: a testi panasz kezelésében, valamint az egészség védelmében (3. táblázat). A testi panasz kezelése és az egészség megörzése is szignifikánsan fontosabb volt az érzékelő csoport számára, mint az intuitívnak. Ez az eredmény jól magyarázható az érzékelő csoportra jellemző realitással, a világ gyakorlatias szempontú megközelítésével.

\begin{tabular}{|c|c|c|c|c|}
\hline & $\begin{array}{c}\text { Személyiség- } \\
\text { preferencia }\end{array}$ & Rangátlag & Mann - Whitney U & Szignifikanciaszint \\
\hline \multirow{2}{*}{ Testi panasz kezelése } & érzékelő & 390,35 & \multirow{2}{*}{63263,500} & \multirow{2}{*}{0,039} \\
\hline & intuitív & 350,00 & & \\
\hline \multirow{2}{*}{ Egészség védelme } & érzékelö & 391,93 & \multirow{2}{*}{62957,500} & \multirow{2}{*}{0,011} \\
\hline & intuitív & 357,02 & & \\
\hline
\end{tabular}

Forrás: Saját vizsgálat, 2017 (N=753)

3. táblázat: Szignifikáns különbségek személyiség alapján a különböző motiváló tényezők fontosságának értékelésében (érzékelés - intuíció)

Megállapítható, hogy az érzékelés és intuíció funkciók alapján elkülönített csoportok között nem volt jelentős különbség a fitneszedzésre járás motivációiban. Míg ebben az esetben kizárólag az egészség védelme és javítása területén volt eltérés, a következő személyiség-dimenzióknál ezen tényezők nem különböztek a két típus között.

A gondolkodó és érző típusú válaszadók között számos eltérésre hívják fel a figyelmet az eredmények. A szignifikáns különbségeket a 4. táblázatban tüntetjük fel. Ezek között a kategóriák között nem volt olyan tendencia megfigyelhetö, mint az extraverzió - introverzió esetében, ahol az extrovertáltak a legtöbb tényezőt magasabbra értékelték, mint az introvertáltak. Bizonyos tendenciák jellemzőek voltak a 
két csoportra a különböző motivációk értékelésében. Szignifikáns eltérést mutatnak az eredmények a szociális tényezők esetében. Mind a társaság $(\mathrm{p}<0,001)$, mind a szórakozás, időtöltés $(\mathrm{p}<0,01)$ szignifikánsan többet számít az érző beállítottságú fitnesz fogyasztóknak, mint a gondolkodóknak. Meghatározó számukra a barátok és ismerősök elvárásai miatt érzett kötelességtudat is $(\mathrm{p}<0,05)$. Az érző típus ismérvei alapján nem meglepő, hogy a lelki feltöltődés jelentősége nagyobb számukra, mint a gondolkodó típusnak $(\mathrm{p}<0,05)$, akik ezzel szemben a másokkal való versengést értékelték motiválóbb szempontnak $(\mathrm{p}<0,05)$.

\begin{tabular}{|c|c|c|c|c|}
\hline & $\begin{array}{l}\text { Személyiség- } \\
\text { preferencia }\end{array}$ & Rangátlag & Mann - Whitney U & Szignifikanciaszint \\
\hline \multirow{2}{*}{ Társaság } & gondolkodó & 352,33 & \multirow{2}{*}{58760,000} & \multirow{2}{*}{$\mathrm{p}<0,001$} \\
\hline & érző & 408,95 & & \\
\hline \multirow{2}{*}{ Szórakozás, időtöltés } & gondolkodó & 358,78 & \multirow{2}{*}{61539,500} & \multirow{2}{*}{0,008} \\
\hline & érző & 400,29 & & \\
\hline \multirow{2}{*}{ Másokkal való versengés } & gondolkodó & 389,65 & \multirow{2}{*}{63078,500} & \multirow{2}{*}{0,028} \\
\hline & érző & 357,62 & & \\
\hline \multirow{2}{*}{ Lelki feltöltődés } & gondolkodó & 362,36 & \multirow{2}{*}{63009,500} & \multirow{2}{*}{0,026} \\
\hline & érző & 395,60 & & \\
\hline \multirow{2}{*}{$\begin{array}{l}\text { Kötelesség: barátok, ismerősök } \\
\text { elvárásai }\end{array}$} & gondolkodó & 365,53 & \multirow{2}{*}{64448,500} & \multirow{2}{*}{0,024} \\
\hline & érző & 390,10 & & \\
\hline
\end{tabular}

Forrás: Saját vizsgálat, 2017 (N=753)

4. táblázat: Szignifikáns különbségek személyiség alapján a különböző motiváló tényezők fontosságának értékelésében (gondolkodó - érző)

Az eredmények azt sugallják, hogy az érző preferenciájú kitöltőknek személyiségtípusuknak megfelelően az emberi szempontok és az érzelmek, nyugalom a hangsúlyosabbak, azaz a társaság, a szórakozás, a barátok és ismerősök elvárásai és a lelki feltöltődés. A gondolkodó típusúak eredmény-orientáltságát tükrözi a versengés nagy szerepe értékelésükben.

Végül a külvilághoz való viszonyulásnak, azaz a megítélés - észlelés dichotómiának a motivációval való összefüggéseit vizsgáltuk. Az ezek alapján elkülönített két csoport között a Mann - Whitney próba szerint mindössze két motivátorral kapcsolatban volt szignifikáns eltérés. Az egyik az alak javítása izomépítéssel, amely az észlelök számára fontosabbnak (rangátlag:399,55) bizonyult, mint a megítélőknek (rangátlag: 356,64) (Mann - Whitney U: 62274,500; p=0,005). A másik tényező a kötelességérzés volt, amelyet a szülök és közeli rokonok elvárásai alakítanak ki (Mann - Whitney U:66008,000; p<0,05). Ezt szintén az észlelő típusúak közé tartozó válaszadók értékelték magasabban (rangátlag: 387,82), mint a megítélők csoportja (rangátlag: 365,79). A többi faktorban nem voltak jelentős eltérések, azonban a szociális tényezőkkel kapcsolatban az a tendencia rajzolódott ki a rangátlagok alapján, hogy némileg többre értékelik ezeket az észlelők a megítélőknél. 


\section{Összefoglalás}

Eredményeink azt tükrözik, hogy a minta egészét tekintve legfontosabb motivációnak a vonzó külső iránti vágy, a kiváló fizikai képességek elérése, az egészség megörzése és fejlesztése, valamint a mentális egészség megteremtése számít. Ezek részben alátámasztják korábbi kutatások megállapításait, amelyek szerint a fitnesz szektor szabadidősportolóira főként a külső megerősítések, az extrinzik motivációk vannak hatással (Kilpatrick, Hebert, Bartholomew, 2010; Frederick, Ryan, 1993), azonban ezektől eltérően mintánkban komoly jelentőséget tulajdonítanak a válaszadók az intrinzik motivációknak, hiszen sokan belső indíttatásból, magáért a sport szeretetéért, a kellemes kikapcsolódás, élmény érdekében járnak fitnesztermi edzésekre. Ezt azért szükséges kihangsúlyozni, mert a fitnesz szolgáltatók az intrinzik motivációkra építve sokkal hosszabb távú és mélyebb elköteleződést tudnak kiépíteni a fitnesz szolgáltatásokat igénybe vevők körében.

Kutatásunk középpontjában annak vizsgálata állt, hogy a fitneszvendégek edzésre járási szokásait valamint a testmozgásra ösztönző legfőbb motivációit befolyásolják-e myersi személyiség-dimenzióik. Eredményeink azt tükrözik, hogy a sportolásba való bekapcsolódás rendszeressége és időtartama nem függ a fitnesz vendégek személyiségétől. A legföbb motivációik alapján azonban már szignifikáns különbségek jelentkeztek a különböző preferencia-dichotómiákban. A minta megoszlása alapján feltételezhetjük, hogy a fitnesztermi edzésekbe leginkább az extrovertált, érzékelö, gondolkodó és megítélő beállítottságú szabadidő-sportolók kapcsolódnak be, így a fitnesz szolgáltatóknak érdemes lehet az erre a típusra jellemző motivációkat és célokat figyelembe véve megszólítani a kívánt célközönséget.

\section{Irodalomjegyzék}

1. Ács Pongrác, Hécz Roland, Paár Dávid, Stocker Miklós (2011): A fittség mértéke. A fizikai inaktivitás nemzetgazdasági terhei Magyarországon. Közgazdasági Szemle. 58 689-708.

2. Apor Péter (2012): Testedzéssel a megbetegedések ellen. Magyar Tudomány. 12 1470-1477.

3. Frederick, C.M., Ryan, R. M. (1993): Differences in motivation for sport and exercise and their relations with participation and mental health. Journal of Sport Behavior. 16 (3) 124-146.

4. Janssen, I. (2012): Health care costs of physical inactivity in Canadian adults. Applied Physiology,Nutrition, and Metabolism. 37 (4) 803-806. DOI: https://doi.org/10.1139/h2012-061

5. Kilpatrick, M., Hebert, E., Bartholomew, J. (2010): College Students' Motivation for Physical Activity: Differentiating Men's and Women's Motives for Sport Participation and Exercise. Journal of American College Health. 54 (2) 87-94. DOI: https://doi.org/10.3200/jach.54.2.87-94 
6. KSH (2014): Európai lakossági egészségfelmérés. Statisztikai tükör. Központi Statisztikai Hivatal. https://www.ksh.hu/docs/hun/xftp/stattukor/elef14.pdf (Letöltés ideje: 2017.06.08).

7. Oliveira, M. R., Da Costa I. F. A. F., Lima de Farias C. R., Oliveira da Silva, M., Simões, C., Medeiros, C. C. M., Franklin de Carvalho, D. (2014): Practice of Physical Activity and Its Relationship with Lipid Profile of Adolescents. Health. 6 2356-2363

http://www.scirp.org/journal/healthhttp://dx.doi.org/10.4236/health.2014.617271 (Letöltés ideje: 2017.02.18.) DOI: https://doi.org/10.4236/health.2014.617271

8. Pavlik Gábor (2015): A rendszeres fizikai aktivitás szerepe betegségek megelőzésében, az egészség megőrzésében. Egészségtudomány. 59 (2)

9. Pratt, M., Norris, J., Lobelo, F., Roux, L., Wang, G. (2014): The cost of physical inactivity: moving into the 21st century. British Journal of Sports Medicine. 48 (3) 171-173. DOI: https://doi.org/10.1136/bjsports-2012-091810

10. Special Eurobarometer (2014): Sport and physical activity. http://ec.europa.eu/commfrontoffice/publicopinion/archives/ebs/ebs_412_en.pd f. (Letöltés dátuma: 2017.10.18.)

11. The Physical Activity Council's annual study tracking sports, fitness and recreation participation in U.S. http://www.physicalactivitycouncil.com/pdfs/ current.pdf (Letöltés dátuma: 2019.04.26.)

12. World Health Organisation (2010): Global Recommendations on Physical Activity for Health. WHO Press, Switzerland 